the descriptions appear in a concise form that makes for easy reading.

There are 66 excellent plates of photographs taken mainly by Sir Harry Champion and Prof. M. V. Laurie which enhance a book the publication of which has long been awaited. Now we feel that the series is a worthy record of forestry and foresters covering some 100 years in the territories we now know as India, Pakistan and Burrna.

C. J. TAYLOR

\section{EXPERIMENTAL PLANT PHYSIOLOGY} Physiology and Biochemistry of Algae

Edited by Ralph A. Lowin. Pp. xxvii +929. (New York: Academic Press, Inc.; London: Academic Press, Inc. (London), Ltd., 1962). $229 s$.

$\mathrm{W}$ E cannot suppose that the physiology of the algae is identical in range and content with the physiology of all other green plants and we cannot deny that those physiological processes in higher plants which are not shared with the algae must carry with them their own particular expression of the relevant biochemical machinery. This being said, it is still evident that the fundamental cellular physiology and biochemistry of all green plants is already expressed in the wide range of plants collectively known as the algae. It has indeed long been clear that the solution of chomical and physical problems in plants is best and most efficiently to be sought by choosing from the wide range of forms among these lowly and, to the layman, relatively unknown organisms, an appropriate plant which can be grown under laboratory conditions under much closer control than could the equivalent, usually much bulkier, higher plant. Wo do not, indeed, have to seek far to find important physiological processes and fundamental molecular structures of which our present understanding owes much, if not all, to the algae-the process of photosynthesis, the mechanisms of salt uptake, the structures of wall and reserve polysaccharides come immediately to mind. It follows that the publication of a book on the physiology and biochemistry of the algae is a more notable event than might at first sight appear. Those of us who know that this book was coming and who had been privileged from time to time to see something of its growth have long awaited it with keen anticipation. We have not been disappointed. The preparation of such a book is a most formidable task embracing not only the vagaries of individual algal groups but also in ossence the whole of plant biochemistry. The editor, the authors and the publisher are to be complimented in rising so admirably to the responsibilities they have undertakon.

This epitome of experimental physiology consists of 55 chapters written by some 60 specialists of a dozen different nationalities with all the consequent dangers of repetition, overlaps and omissions. Omissions there must inevitably be even in a book of 929 pages but in all other respects the editing of this book has been little short of superb. The four parts into which the book is divided deal rospoctively with nutrition and metabolism, composition of cells and metabolic products, permeability, and physiological aspects of ecology, and there are appendixes on classification of algae, on uptake of radioactive wastes by algae and on antibiotics from algae. It would be invidious to pick out any particular chapter for special comment; the authors all keep to the point and with rare exceptions the style is clear and the expression unambiguous. The chapters range in subject-matter from light reactions in photosynthesis to extracellular products; from permeability to cell division; from nucleic acids to the polysaceharidos of cell walls.

It is nowadays the fate of all scientific books to be out of date on publication and some chapters in this book are no exception. This is, however, to some extent offset by the froedom with which many authors have quoted from their own unpublished findings. When writing concisely, moreover (especially, as here one is told, under the lash of an editor's whip), it is the easier way to allow one's understandable enthusiasm for one's own work to minimize the space devoted to others'. Without exception the authors hero tread a harder path, and not the least valuable feature of the book is the copious bibliography appended to each chapter. The presentation of the book is of a high standard with adequate illustration, and with an author index, a subject index and a taxonomic index.

As one of those sad figures portrayed on the second page of the preface, an authority, perhaps, in a restricted field, not particularly august but certainly with a worn pen, I have nothing but praise for this effort of "the younger generation" produced in the "chaos of their laboratories". This is a book written and produced by workers at the bench, for workers at the bench into which the august are allowed to dip to keep their minds alert and their pronouncements informed. It is not a book which can be read from cover to cover; it is a guide book over which research worker and teacher alike will need to pore and to ponder. No one even remotely involved in the chemistry and physics, not only of algae but also of any plants, can afford to miss this book. It is a record of achievement over the past few years which some other sciences may match but none can beat, a book which cannot be allowed to moulder on a library shelf but which each will want to buy for his own private enjoyment. It is all the more a pity that such a book has to be so expensive.

R. D. Preston

\section{RETURN FROM CLINICAL DEATH}

Resuscitation and Artificial Hypothermia

By V. A. Negovskii. Authorized translation from the Russian by Basil Haigh. Pp. xiv +314 . (New York: Consultants Bureau, 1962.) 12.50 dollars.

THE changes seen in potentially lethal but reversible states occur also during cardiac operations involving arrest of the circulation and in inefficient perfusion by heart-lung machines. Their investigation, detection, prevention and treatment are the themes of this book and it is therefore of interest to many in ways not apparent from its title. It is a monograph based on the experimental and clinical experience of its author, who is the head of the Laboratory of Experimental Physiology of Resuscitation of the U.S.S.R. A.cademy of Modical Sciences, and reinforced by references to the literature, nearly twothirds of which are from non-Soviet sources.

Its familiarity with non-Soviot work is obvious, but it is influenced by Soviet inexperience in some fields which detracts from its value. Its attitude to general anæsthesia end its supposed dangers is an example in point. It has also the disadvantage that the original appeared in 1960 and although revisions have been made for this translation most references date from prior to 1958 , which in such an active field is a distinct drawback. To those ignorant of the U.S.S.R. and her science, it is of great interest as a record of the work of this Laboratory and as a summary of Soviet work in this field. It is apparent that while development has in most respects been parallel in and outside the U.S.S.R. the Soviet research workers have been ahead in their interest in the subject of resuscitation and in some aspects of its investigation.

The exporimental mothod used is that of bleoding to clinical death with resuscitation by artificial respiration and intra-arterial transfusion. This has obvious parallels in elinical practice, but it would seem limited as e mothod of invostigating anoxia and anæmia bocause of its imprecise end points, and the author's purpose would appear to be better served by methods producing complete cessetion of eirculation at a precisely determined time. 